\title{
SIMULATION OF TRAFFIC POLLUTION DISPERSION NEAR ROADWAYS
}

\author{
B. Martinėnas and V. Špakauskas \\ Faculty of Fundamental Sciences, Vilnius Gediminas Technical University, Sauletekio 11, LT-10223 Vilnius, Lithuania \\ E-mail: vspaka@takas.lt
}

Received 10 March 2010; revised 30 April 2010; accepted 17 June 2010

\begin{abstract}
A semi-empirical model intended for simulation of dispersion of aerosol particles with the diameter larger than $0.05 \mu \mathrm{m}$ near roadways is proposed. The pollution source is simulated as a cut-off cylinder, formed due to traffic pollution on the roadways at the initial time moment and uniformly filled with aerosol particles. The aerosol particle transfer by the wind further from the roadway is simulated, its settling being influenced by the gravitation, particle buoyancy, and thermal pollutant plume rise effects. Good agreement between the model and experimental results is obtained.
\end{abstract}

Keywords: modelling, traffic pollution, aerosol particles $(>0.05 \mu \mathrm{m})$, roadside

PACS: 92.60.Sz, 91.62.Rt, 92.60.Mt, 91.67.gp

\section{Introduction}

Traffic pollution constitutes a considerable part of pollutants in all countries. The pollutants can most heavily contaminate the $40-60 \mathrm{~m}$ wide roadside zone, while the overall polluted area extends to the approximately $300 \mathrm{~m}$ wide zone [1-3], and the number concentration of particles smaller than $0.3 \mu \mathrm{m}$ in diameter, which can be inhaled and cause serious health effects, is dominating $[4,5]$.

At present for the description of the road pollution dispersion, different types of dispersion models are used: box type, Gaussian, Eulerian and Lagrangian, computational fluid dynamic, semi-empirical, stochastic, and deterministic-statistical models, in which the point, line, area, and volume type sources are most frequently used [6-9] In the atmospheric dispersion simulation, Gaussian type models are most widely used. The basis of the description of Gaussian type models is a simplified diffusion equation, which describes a continuous cloud of material dispersion in a turbulent flow. The solution of this equation is the Gaussian plume model, which is at the core of almost all regulatory dispersion models. In practical applications the line, plane, and volume sources are subdivided into parts by attributing them separate Gaussian plume equations, including the vehicle-induced turbulence, meteorological state parameters, etc. In such a way the problems of pollution dispersion of line [8] and volume [9] sources are solved, and good dispersion conformity with the experimental data is obtained. Besides, the pollution concentration decrease receding from the roadside is usually close to the exponential law. Due to the complexity of applied models, more convenient approaches for the dispersion interpretation are sought, e. g. by changing the line model by a semi-empirical dispersion model, which allows interpreting air quality and meteorological measurements [10].

The number size distribution has a typical bimodal structure with a concentration maximum of 0.02 $0.03 \mu \mathrm{m}$ in the aerosol particle size range of $0.01-$ $0.05 \mu \mathrm{m}$, formed by supersaturation due to a rapid cooling of traffic exhaust gas [11], and the second peak of about $0.1 \mu \mathrm{m}$ in the aerosol particle size range of $0.05-$ $0.3 \mu \mathrm{m}$ is formed after incomplete combustion and is caused by soot particles emitted especially by diesel vehicles into the atmosphere [12]. The dispersion of particles in the size range of $0.01-0.05 \mu \mathrm{m}$ and $0.05-0.3 \mu \mathrm{m}$ differs substantially. The concentration of the first size range aerosol particles receding from the roadside decreases according to the law close to exponential, while the concentration of the second size range aerosol particles receding from the roadside decays more slowly, moreover, with further receding from the road a local concentration increase is observed, its place depending on the wind speed $[2,13]$.

Similar results were obtained by measuring soil (at the depth of $10 \mathrm{~cm}$ ) and plant pollution with trace metals 


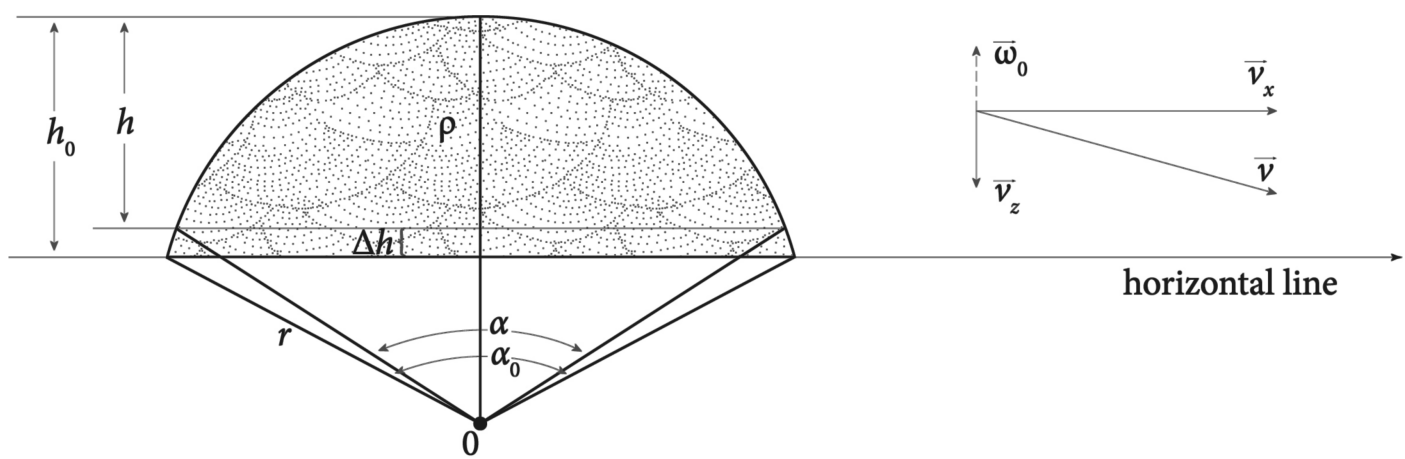

Fig. 1. Settling of the plume on the ground surface.

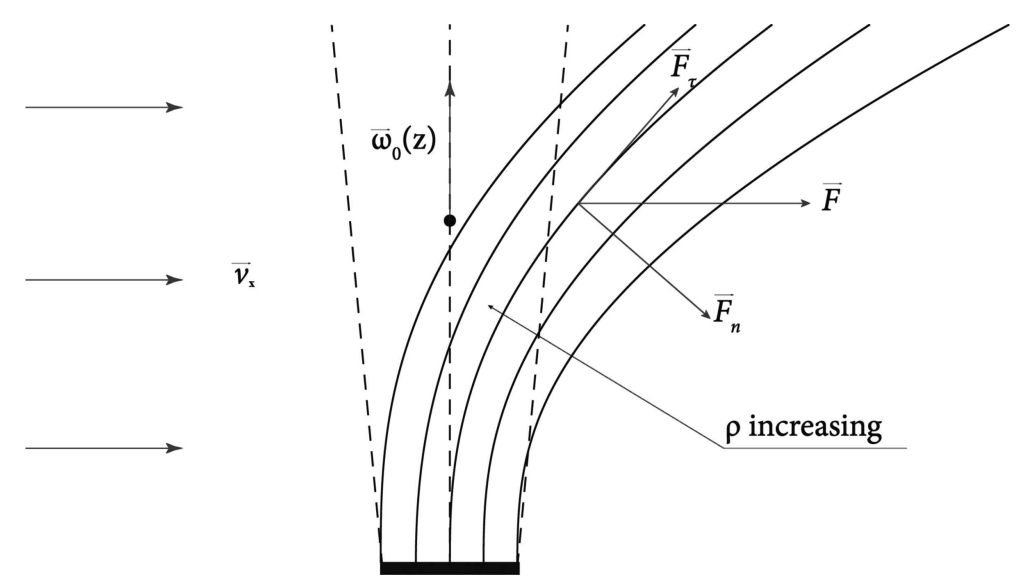

Fig. 2. The bent of the plume in the wind.

depending on the traffic levels in France near roadways [3] and analogous measurements at selected points near main roadways in Lithuania [14].

Having introduced empirical parameters, the dispersion of aerosol particles in the size range of $0.01-$ $0.05 \mu \mathrm{m}$ is well described by the Gaussian plume model [8], but this model cannot explain the dispersion peculiarities of aerosol particles in the size range of 0.05 $0.3 \mu \mathrm{m}$, though there have been attempts to interpret it as a particle coagulation phenomenon. The aerosol particles belonging to the size range of $0.05-0.3 \mu \mathrm{m}$ are formed during atmospheric oxidation processes, which are relatively slow [12]. Namely these aerosol particles transfer trace heavy metals, the main sources of which are lubricant additives, rubber stabilizers, brake materials, their concentrations being most often measured in the air, plants, and soil $[2,3,14]$.

The aim of the work is to develop a model including the gravitation, buoyancy, and thermal effects, intended for simulation of the traffic pollution dispersion of aerosol particles larger than $0.05 \mu \mathrm{m}$ near roadways as well as using the volumetric source physical model to explain experimentally measured dispersion peculiarities of aerosol particles.
We assume that the coagulation process is not essential for the dispersion of mentioned particles and the vehicle-induced mechanical and thermal turbulence has the greatest influence on it.

\section{Description of a physical model}

We are proposing a settling scheme for a plume of aerosol particles on the ground surface shown in Fig. 1, which illustrates the dispersion of fine aerosol particles. When there is no wind, the cylindrical plume, formed by the vehicle-induced mechanical and thermal turbulence, immediately gets a cut-off cylindrical shape, the width of which is equal to the roadway width and the radius of which is $r$ with the height $h_{0}$ (Fig. 1). When the crosswind speed is $v_{x}$ and it is directed perpendicularly to the roadway, the cylindrical plume moves downwind with the velocity $v_{x}$ and settles slowly falling at a constant velocity $v_{z}$ by the roadside. Let us assume that the density $\rho$ of fine aerosol particles in the cloud is $\rho=n / V_{0}$, where $n$ is the number of aerosol particles in the volume $V_{0}, \rho$ is the constant in the initial model, and $\omega_{0}$ is the rising velocity of the cloud of aerosol particles. 
The cloud carried by the wind at the distance $\Delta x$ shifts downwards at $\Delta h$ and the whole aerosol particle cloud settles at the distance $x_{\max }$ from the road:

$$
\Delta h=\frac{v_{z}}{v_{x}} \Delta x, \quad \frac{v_{z}}{v_{x}}=\frac{h_{0}}{x_{\max }} .
$$

The volume $V(\alpha)$ of the cloud is equal to the area, which is the cut-off circle multiplied by the length $l$ of the plume located along the roadway:

$$
V(\alpha)=\frac{l r^{2}}{2}(\alpha-\sin \alpha) .
$$

The initial angle $\alpha_{0}$ corresponds to the initial volume $V_{0}=V\left(\alpha_{0}\right)$.

Assuming the unit length $l$ of the aerosol particle cloud, the number of settled particles by the roadside is equal to the number of particles in the cut-off alteration $\mathrm{d} n$, which is limited by the height $\Delta h$.

The probability density function $f(\alpha)$ obtained according to definition is given by

$$
f(\alpha)=\frac{\mathrm{d} n}{n \mathrm{~d} \alpha}=\frac{\rho \mathrm{d} V}{n \mathrm{~d} \alpha}=\frac{1}{V_{0}} \frac{\mathrm{d} V(\alpha)}{\mathrm{d} \alpha}=\frac{1-\cos \alpha}{\alpha_{0}-\sin \alpha_{0}},
$$

where $\alpha_{0} \geq \alpha \geq 0, \alpha_{0}$ is the angle of the cylinder segment at the initial time moment, and the angle $\alpha$ when the cylinder settles by $\Delta h$ (Fig. 1 ).

As seen in Fig. 1,

$$
\begin{gathered}
h=h_{0}-\Delta h=h_{0}-\frac{v_{z}}{v_{x}} \Delta x, \\
h=r\left(1-\cos \frac{\alpha}{2}\right) .
\end{gathered}
$$

From Eqs. (4) and (5) it follows that the distance $\Delta x$ passed by the plume in the downwind direction and the angle $\alpha$ (Fig. 1) are

$$
\begin{aligned}
& \Delta x=r\left(\cos \frac{\alpha}{2}-\cos \frac{\alpha_{0}}{2}\right) \frac{v_{x}}{v_{z}}, \\
& \cos \frac{\alpha}{2}=1-\frac{1}{r}\left(h_{0}-\frac{v_{z}}{v_{x}} \Delta x\right) .
\end{aligned}
$$

It is known that the gravitation has influence on the aerosol particle probability density distribution in the plume. On the other hand, aerosol particles are additionally influenced by the heated air flow rising from the roadside and by the buoyancy effect. With the particle rising and the crosswind blowing, the phenomenon similar to the spreading of burning products, emitted from the source during wind, occurs (Fig. 2). If we divide the wind-induced power force $\vec{F}$ into components $\vec{F}_{n}$ and $\vec{F}_{t}$, the flow affected by the power $\vec{F}_{n}$ moves downwind, as a result of which the particle concentration downwind becomes higher. This was confirmed by the investigations [15] of the vertical distribution of aerosol particles and $\mathrm{NO}_{x}$ close to a roadway on the downwind side carried out in Germany, when the wind speed was $2.2 \mathrm{~m} / \mathrm{s}$. It was determined that the former particle concentration maximum in the forenoon was near the ground surface, but at about noon it slightly shifted to $10 \mathrm{~m}$ above the ground for aerosol particles less than $0.3 \mu \mathrm{m}$, while upwind the aerosol particle concentration remained constant up to the $50 \mathrm{~m}$ height. For the aerosol particle size range of $0.3-0.7 \mu \mathrm{m}$, no height dependence was found.

For the mentioned reason during the initial rise period an upward tendency of the aerosol particle concentration increase is formed [16]. We include the mentioned gravitation, buoyancy, and thermal effects as the probability density function factor $g(\Delta h)$ :

$$
g(\Delta h)=\frac{1}{N}\left(\mathrm{e}^{-a \Delta h}+c \mathrm{e}^{b \Delta h}\right),
$$

where $a$ and $b$ express the gravitation and buoyancy coefficients, $c$ is the relative weight of buoyancy contribution, $\Delta h_{\max }$ is the initial height of a plume, $N$ is the normalizing coefficient:

$$
N=\frac{1}{a}\left(1-\mathrm{e}^{-a \Delta h_{\max }}\right)-\frac{c}{b}\left(1-\mathrm{e}^{b \Delta h_{\max }}\right) .
$$

Therefore, we multiply the probability density function $f(\alpha)$ by the coefficient $g(\Delta h)$ and obtain the probability density function $\gamma(\alpha, \Delta h)$ :

$$
\gamma(\alpha, \Delta h)=f(\alpha) \cdot g(\Delta h) .
$$

Passing from the probability density function to the quantitative concentration evaluation, the probability density function $\gamma(\alpha, \Delta h)$ should be multiplied by the emission rate per unit length $Q[\mathrm{~kg} /(\mathrm{m} \mathrm{s})]$.

For the plume vertical movement apart from the falling velocity $\vec{\nu}_{z}$, the plume rise velocity $\vec{\omega}_{0}(z)$ is introduced, thus the movement in the $z$ axis direction proceeds at the $\vec{\nu}_{z}+\vec{\omega}(z)$ velocity. According to the movement law of pollutants emitted from the source, the rise velocity $\omega_{0}(z)$ of this plume depends on the height $z$ of the plume rise above the source, and the velocity of centerline of the plume is expressed as [17]

$$
\omega_{0}(z)=C_{1} B^{1 / 3} z^{-1 / 3},
$$

where $C_{1}$ is a dimensionless constant, $B$ is the buoyancy flux constant. 


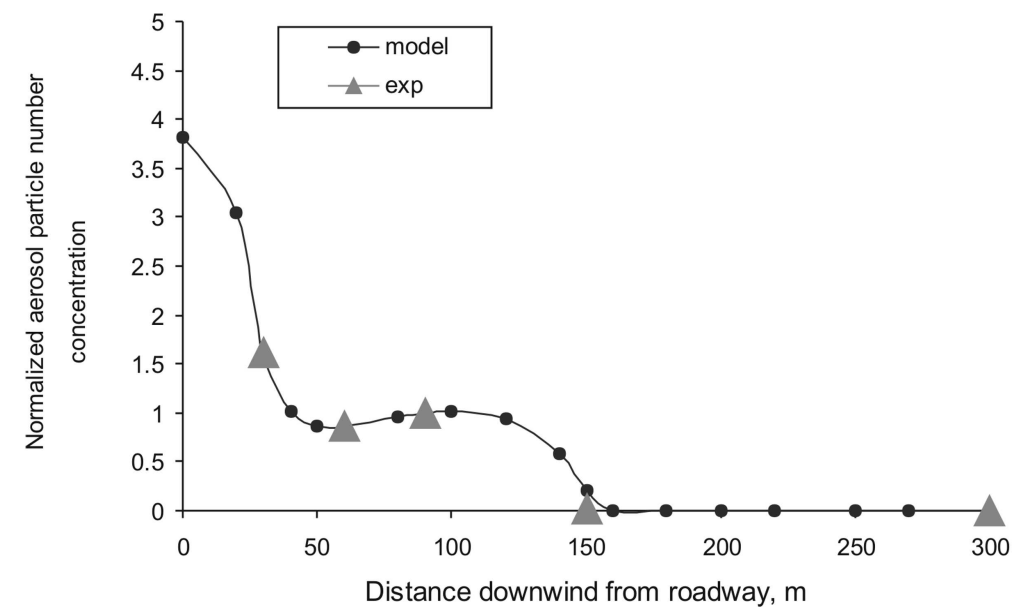

Fig. 3. Dependence of normalized experimental [2] and current work model aerosol particle concentrations on the distance from the roadway when the wind speed is $1 \mathrm{~m} / \mathrm{s}$.

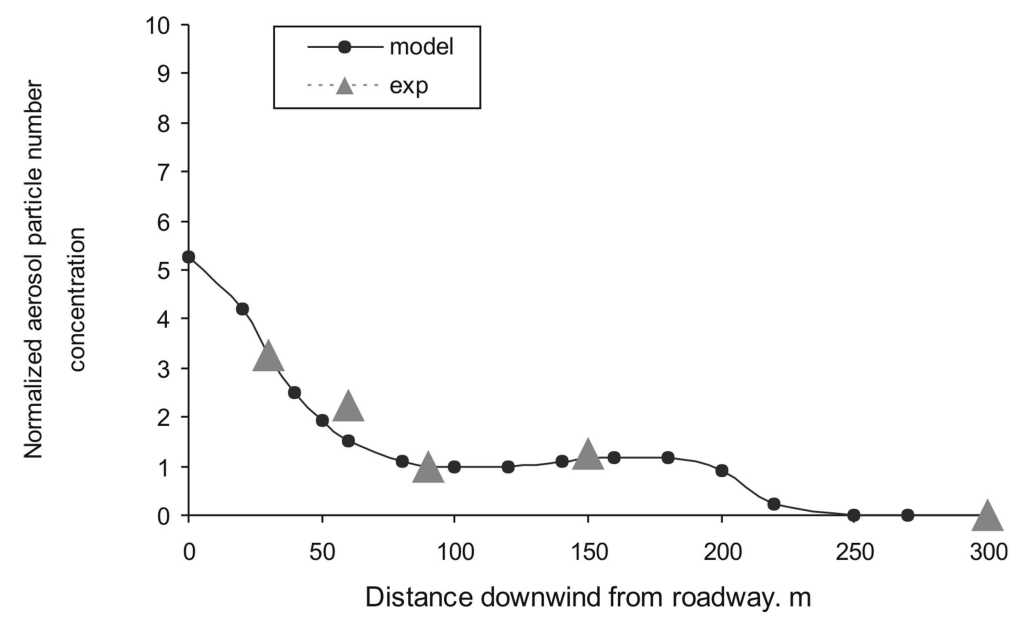

Fig. 4. Dependence of normalized experimental [2] and current work model aerosol particle concentrations on the distance downwind from the roadway when the wind speed is $2.5 \mathrm{~m} / \mathrm{s}$.

\section{Results and discussions}

For the validation of the model developed in our study, the experimental data obtained in [2] were used. Substantial changes in the investigations of the traffic pollution dispersion near roadways were obtained by Zhu et al. during the experiment in the vicinity of roadways in the Los Angeles area using the CPC 3022A aerosol particle counter for measuring the aerosol particle number concentration and the SMPS 3936 aerosol particle seizer for the aerosol particle size distribution with expected error $\pm 10 \%[2,13]$. The aerosol particle number concentration and the size distribution in the size range from 0.006 to $0.22 \mu \mathrm{m}$ were measured. Measurements were carried out at a distance of $30,60,90$, 150 , and $300 \mathrm{~m}$ downwind from the central line of the highway, which is $30 \mathrm{~m}$ wide, when the average crosswind velocity was 1 and $2.5 \mathrm{~m} / \mathrm{s}$. A general concentration decrease of all aerosol particles receding from the roadway and the dependence of their fraction dispersion on the particle size were obtained.

It has been determined that the number concentration for all size aerosol particles dropped to approximately half its original value at the distance somewhere between 90 and $150 \mathrm{~m}$. The decrease of the normalized total particle number and volume concentration in the size range of $0.006-0.22 \mu \mathrm{m}$ is close to the exponential law, but in the size range of $0.05-0.1$ and $0.1-0.22 \mu \mathrm{m}$ a decrease has some peculiarities. For these size ranges, when the wind speed is $1 \mathrm{~m} / \mathrm{s}$ at the $60 \mathrm{~m}$ distance from the roadway, in the concentration diagram a small hole is observed, while at the $90 \mathrm{~m}$ distance from the roadway the concentration increase is observed. When the wind speed is $2.5 \mathrm{~m} / \mathrm{s}$, the minimum of the particle size range of $0.05-0.1 \mu \mathrm{m}$ shifts towards $90 \mathrm{~m}$, and the maximum towards $150 \mathrm{~m}$. For the size range of $0.1-$ $0.22 \mu \mathrm{m}$, the concentration extremums of these aerosol particles disappear completely. 
The probable rising velocity $\omega_{0}$ of the plume over the road at the $1 \mathrm{~m}$ height was evaluated in [18] by improving the common Gaussian line source model, where equations evaluating the plume rise speed were obtained. From these equations it follows that under neutral atmospheric conditions, when the wind speed is 1 and $2.5 \mathrm{~m} / \mathrm{s}$, the plume rising velocity is 0.062 and $0.042 \mathrm{~m} / \mathrm{s}$, respectively.

The optimal probability density function was obtained when $\alpha_{0}=4.8 \mathrm{rad}$ (it corresponds to the maximal plume height over the road), with the road half width $r=15 \mathrm{~m}$. When the wind speed $v_{x}=1$ and $2.5 \mathrm{~m} / \mathrm{s}$, then $v_{z}=0.06$ and $0.08 \mathrm{~m} / \mathrm{s}$, and $\omega_{0}=0.045$ and $0.04 \mathrm{~m} / \mathrm{s}$. In the probability density function the gravitation and buoyancy effects resulted in statistical weights $1 / N=0.33$ and $c / N=0.066$ when the wind speed $v_{x}=1 \mathrm{~m} / \mathrm{s}$, and $1 / N=0.36$ and $c / N=0.025$ when the wind speed $v_{x}=2.5 \mathrm{~m} / \mathrm{s}$. Gravitation and buoyancy coefficients $a$ and $b$ at the wind speed $v_{x}=$ $1 \mathrm{~m} / \mathrm{s}$, are $a=5.0, b=0.55$, and at $v_{x}=2.5 \mathrm{~m} / \mathrm{s} a=$ $2.0, b=0.85$.

For the intermediate wind rates, corresponding data for the aerosol particle concentration versus distance could be easily obtained by interpolation. For the higher wind speed, however, additional measurements should be performed.

The normalized (equated to one in a point of concentration values at the distance of $90 \mathrm{~m}$ ) model and experimental [2] curves, when the wind speeds $v_{x}$ are 1 and $2.5 \mathrm{~m} / \mathrm{s}$, are shown in Figs. 3 and 4. Many experiments show that motor vehicle pollutants spread at the distance of up to $300 \mathrm{~m}$ from the roadway, thus the pollutant concentration at the $300 \mathrm{~m}$ distance from the roadside can be considered as background. Therefore, if we do not include the background concentration in our model, the experimental concentration value at the $300 \mathrm{~m}$ distance should be equal to 0 .

The correlation coefficient between the model and experimental data, when the wind speed $v_{x}=1 \mathrm{~m} / \mathrm{s}$, was 0.99 , and when $v_{x}=2.5 \mathrm{~m} / \mathrm{s}$, it was 0.96 .

\section{Conclusions}

A semi-empirical model intended for simulation of dispersion of aerosol particles with the diameter larger than $0.05 \mu \mathrm{m}$ near roadways has been proposed in the work. Mathematically described dispersion of aerosol particles $(>0.05 \mu \mathrm{m})$ in a pollution source allows simulation of the pollutant concentration change near roadways. Experimental data [2] show that the dispersion of aerosol particles in the size ranges of $0.05-0.1$ and $0.1-$ $0.22 \mu \mathrm{m}$ depends on the wind speed. When the wind speed is $1 \mathrm{~m} / \mathrm{s}$, the concentration of aerosol particles of both size ranges at the beginning decreases at the distance of up to $60 \mathrm{~m}$ from the road, and increases at the distance of $90 \mathrm{~m}$, but further it decreases again. When the wind speed is $2.5 \mathrm{~m} / \mathrm{s}$, the concentration decrease of aerosol particles in the size range of $0.05-0.1 \mu \mathrm{m}$ is observed at the distance of up to $90 \mathrm{~m}$, and an increase at up to $150 \mathrm{~m}$, but further it again decreases. The concentration of aerosol particles in the size range of $0.1-$ $0.22 \mu \mathrm{m}$, when the wind speed is $2.5 \mathrm{~m} / \mathrm{s}$, decreases uniformly receding from the road.

By simulating the pollution source as a cut-off cylinder, formed on the roadway at the initial time moment due to traffic pollution and uniformly filled with aerosol particles, and with their transfer by the wind further from the roadway, the aerosol particle settling is influenced by the gravitation, particle buoyancy, and thermal pollutant plume rise effects. The obtained aerosol particle concentration change near roadways better coincides with the experimental data $[2,3,13,14]$.

\section{References}

[1] D. Martuzevicius, S.A. Grinshpun, T. Reponen, R.L. Gorny, R. Shukla, J. Lockey, S. Hu, R. McDonald, P. Biswas, L. Kliucininkas, and G. LeMasters, Spacial and temporal variations of $\mathrm{PM}_{2.5}$ concentration and composition throughout an urban area with high freeway density - the Greater Cincinati study, Atmos. Environ. 38, 1091-1105 (2004).

[2] Y. Zhu, W.C. Hinds, S. Kim, and C. Sioutas, Concentration and size distribution of ultrafine particles near a major highway, J. Air Waste Manag. Assoc. 52, 10321042 (2002).

[3] Roadside soil and plant pollution, Information note. Economy, Environment, Design 73 (SETRA, 2005), http://www.setra.equipement.gouv.fr/IMG/pdf /US_NI_EEC_073_GB.pdf .

[4] N. Li, M. Hao, R.F. Phalen, W.C. Hinds, and A.E. Nel, Particulate air pollutants and asthma: A paradigm for the role of oxidative stress in PM-induced adverse health effects, Clin. Immunol. 109(3), 250-265 (2003).

[5] J. Ovadnevaitè, K. Kvietkus, and A. Maršalka, 2002 summer fires in Lithuania: Impact on the Vilnius city air quality and the inhabitants health, Sci. Total Environ. 356, 11-21 (2006).

[6] N.S. Holmes and L. Morawska, A review of dispersion modeling and its application to the dispersion of particles: An overview of different dispersion models available. Atmos. Environ. 40, 5902-5928 (2006). 
[7] S. Gokhale and M. Khare, A review of deterministic, stochastic and hybrid vehicular exhaust emission models, Int. J. Transport Manag. 2, 59-74 (2004).

[8] K.S. Rao, R.L. Gunter, J.R. White, and R.P. Hosker, Turbulence and dispersion modeling near highways, Atmos. Environ. 36, 4337-4346 (2002).

[9] A.M. Sahlodin, R. Sotudeh-Gharebagh, and Y. Zhu, Modeling of dispersion near roadways based on the vehicle-induced turbulence concept, Atmos. Environ. 41, 92-103 (2007).

[10] A. Venkatram, V. Isakov, E. Thoma, and R. Baldauf, Analysis of air quality data near roadways using a dispersion model, Atmos. Environ. 41, 9481-9497 (2007).

[11] N. Bukowiecki, J. Dommen, A.S.H. Prevot, R. Richer, E. Weingartner, and U. Baltensperger, A mobile pollutant measurement laboratory - measuring gas phase and aerosol ambient concentrations with high spatial and temporal resolution, Atmos. Environ. 36, 55695579 (2002).

[12] U. Baltensperger, N. Streit, E. Weingartner, S. Nyeki, A.S.H. Prevot, R. Van Dingen, A. Virkkula, J.P. Putaud, A. Even, H. ten Brink, A. Blatter, A. Neftel, and H.W. Gäggeler, Urban and rural aerosol characterization of summer smog events during the PIPAPO field campaign in Milan, Italy, J. Geophys. Res. 107(D22), 8193 (2002).
[13] Y. Zhu, W.C. Hinds, S. Kim, S. Shen, and C. Sioutas, Study of ultrafine particles near a major highway with heavy - duty diesel traffic, Atmos. Environ. 36, 43234335 (2002).

[14] S. Juknevičius, D. Matyžiūtė-Juodkienė, and N. Sabiené, Contamination of soil and grass by heavy metals along the main roads in Lithuania, Ecology 53(3), 7074 (2007).

[15] D. Imhol, E. Weingartner, U. Vogt, A. Dreiseidler, E. Rosenbohm, V. Scheer, R. Vogt, O.J. Nielsen, R. Kurtenbach, U. Corsmeier, M. Kohler, and U. Baltensperger, Vertical distribution of aerosol particles and $\mathrm{NO}_{x}$ close to a motorway, Atmos. Environ. 39, 57105721 (2005).

[16] W.C. Hinds, C. Sioutas, and Y. Zhu, Relationship between ultrafine particle size distribution and distance from highway (National Center for Environ. Res. \& Quality Assurance, 2004). http://cfpub1.epa.gov/ ncer_abstracts/index.cfm/fuseaction/display. abstractDetail/abstract/6984/report/F.

[17] P. Linden, Plume dynamics, Mechanical and Environmental Engineering Laboratory (2010), http:// maecourses.ucsd.edu/labcourse/lecturenotes/Plume_ lecture_2010.pdf.

[18] D.P. Chock, A simple line-source model for dispersion near roadways, Atmos. Environ. 12, 823-829 (1978).

\title{
AUTOTRANSPORTO TERŠALŲ SKLAIDOS PAKELĖJE MODELIAVIMAS
}

\author{
B. Martinėnas, V. Špakauskas \\ Vilniaus Gedimino technikos universitetas, Vilnius, Lietuva
}

\begin{abstract}
Santrauka
Darbe pasiūlytas kvaziempirinis modelis, skirtas didesnio nei $0,05 \mu \mathrm{m}$ skersmens dalelių sklaidai pakelèje modeliuoti ir [2] darbe pateiktiems eksperimentiniams rezultatams aprašyti. Matematiškai aprašytas aerozolio dalelių $(>0,05 \mu \mathrm{m})$ pasiskirstymas taršos šaltinyje leidžia sumodeliuoti teršalų koncentracijos kaitą transporto magistralès šalikelèje. Eksperimentiniai duomenys [2] rodo, kad aerozolio dalelių, priklausančiu $0,05-0,1$ ir $0,1-0,22 \mu \mathrm{m}$ frakcijoms, sklaida priklauso nuo pažemio vèjo greičio. Kai vėjo greitis buvo $1 \mathrm{~m} / \mathrm{s}$, abiejų frakcijų aerozolio dalelių koncentracija pradžioje mažèjo iki $60 \mathrm{~m}$ nuo kelio ir vèl padidejo ties $90 \mathrm{~m}$, o toliau
\end{abstract}

vèl mažèjo. Kai vèjo greitis $2,5 \mathrm{~m} / \mathrm{s}, 0,05-0,1 \mu \mathrm{m}$ dydžio aerozolio dalelių koncentracijos mažèjimas buvo stebimas iki $90 \mathrm{~m}$, didèjimas - iki $150 \mathrm{~m}$, o toliau vèl mažèjimas. Kai pažemio vèjo greitis buvo $2,5 \mathrm{~m} / \mathrm{s}, 0,1-0,22 \mu \mathrm{m}$ dydžio aerozolio dalelių koncentracija tolstant nuo kelio mažèjo tolygiai. Modeliuojant taršos šaltini kaip nupjautini cilindrą, kuris pradiniu laiko momentu dèl autotransporto taršos susiformuoja ant kelio ir yra tolygiai užpildomas aerozolio dalelèmis, vèjo nešamomis tolyn nuo kelio bei veikiamomis gravitacijos, dalelių plūdrumo ir terminio kilimo efektų, gauname aerozolio dalelių koncentracijos kaitą šalikeleje geriau derančią su eksperimentiniais duomenimis $[2,3,13,14]$. 